\title{
アジア高山域起源の大河川流域における 21 世紀の氷河融解の進行之 年流出量変化への影響 \\ GLACIER MELT RESPONSE \\ AND ANNUAL HYDROLOGICAL IMPACT \\ THROUGHOUT TWENTY-FIRST CENTURY \\ FOR MAJOR RIVER BASINS ORIGINATING IN HIGH MOUNTAIN ASIA
}

\author{
渡辺恵 $^{1} \cdot$ Sujan Koirala $^{2}$ - 平林由希子 ${ }^{3}$ ・鼎信次郎 ${ }^{4}$ \\ Megumi WATANABE, Sujan KOIRALA, Yukiko HIRABAYASHI, Shinjiro KANAE \\ 1 学生会員 東京工業大学大学院情報理工学研究科 学生（干152-8552 東京都目黒区大岡山 2-12-1） \\ 2 正会員 博士 (工学) Department of Biogeochemical Integration, Max Planck Institute for Biogeochemistry 研究員 \\ (Jena, Thüringen, 07745, Germany) \\ 3 正会員 博士（工学） 東京大学大学院工学研究科 准教授（干113-8656 東京都文京区弥生 2-11-16) \\ 4 正会員 博士（工学） 東京工業大学理工学研究科 教授（干152-8552 東京都目黒区大岡山 2-12-1）
}

\begin{abstract}
It is unclear glacier melt response (e.g., the magnitude and timing of changes in glacier melt) and the extent of contribution of glacier melts towards river flow in the context of climate change for major river basins originating in High Mountain Asia. Here we evaluate glacier melt response to climate change at major river basin scale for 11 basins using glacier melts estimated by a glacier model. Furthermore, we attempt to add the runoff outputs of climate models with the glacier melts into a "total runoff" to reveal the hydrological impact of the glacier melts. Our simulation implied that the glacier melt response of climate change is regionally different. However, the annual total runoff would increase caused by primarily an increase in non-glacier melt components across 11 basins until the end of 21 st century. The relative contribution of glacier melts to the total runoff would significantly decrease towards the end of 21 st century in some basins and it might have implications on seasonal water supplies.
\end{abstract}

Key Words : glacier melt, runoff, GCM, glacier model, High Mountain Asia

\section{1. はじめに}

カラコルム山脈やヒマラヤ山脈などから成るアジア 高山域の水河からの融解水は，インダスやガンジス， 長江，黄河などのアジアの主要な大河川の起源となっ ている.このアジア高山域では，過去数十年において 昇温に起因する水河の質量損失が観測されており，21 世紀を通して加速することが予測されているため ${ }^{1)}$, 水河融解がアジアの大河川の水資源一甚大な影響を及 ぼすことが懸念されている ${ }^{2), 3)}$.

気候変化により水河質量が加速的に損失する場合に は，多くの水河において水河からの融解水が一時的に 増加する. しかし, さらに融解が進行して氷河が縮退 すると, 毎年の水河からの融解水量は増加から減少へ 転じることが知られている (図-1） ${ }^{4)}$.このような水河 の気候変化への応答としての融解量の変化は，水河下
流の水資源を考える上で重要な情報であるが，水河融 解の進行度合いや水河融解量が増加から減少に転じる 時期などは，限られた氷河についてしか予測されてい ない. たとえば，インダスやガンジス流域内の一部の 水河からの融解量は，21世紀の半ばから後半にかけて 増加から減少へ転じることが予測されている ${ }^{5,6)}$. しか し，アジアの大河川の水資源の将来展望を考える上で は，このような一部の水河からの融解量だけではなく， アジア高山域におけるすべての水河からの融解量の将 来変化を求め, 気候変化に対するアジア高山域全体と しての水河の応答や，流域や気候区などの領域毎の水 河の応答の違いを明らかにする必要があると思われる. また，氷河融解量の変化は下流の大流域などにおけ る広域水資源へ影響を与えることが懸念されているが， アジア高山域下流の大河川を対象に氷河融解量を考慮 して流出量の将来予測を行った研究は, 1-2 例に限られ 


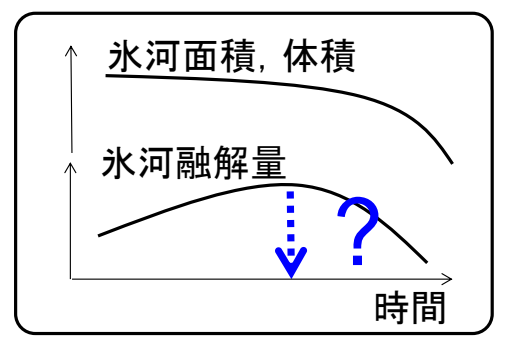

図-1 水河融解の進行と水河融解量の時間変化

ており，かつ大河川の上流域のみに着目している ${ }^{7), 8)}$. たとえば，ガンジス，ブラマプトラ， サルウィン，メ コンの上流では降水の増加が主原因となって将来の流 出量の増加が予測される一方で, インダス上流では水 河融解水の増加が主原因となって流出量が増加するこ とが予測されている7)。しかしながら，広域水資源へ の水河融解の影響を評価するためには，上流域だけで はなく，流域全体について見通す必要がある。また， アジア高山域の水河を起源とする流域の特徵は様々で あり，上記の 5 河川以外の他の流域の流出についても 調査する必要がある. 加えて, 将来予測にはモデルに よる不確実性がともなうために，既存研究とは異なる 氷河モデルなどを用いることにも意義がある.

以上の背景より, 本研究では, まず, アジア高山域 全体や，アジア高山域内の領域毎（流域）の水河融解 量の将来変化を独自の水河モデルを用いて明らかにし， アジア高山域における水河の気候変化に対する応答の 整理を行う。次に，アジア高山域が流域に含まれるす べての大河川を対象に氷河融解量を考慮した流域全体 の河川流出量の将来予測を行い, 水河融解が下流の水 資源に及ぼす影響を定量化することを目的とする.

\section{2. 手法}

\section{(1) 概要}

対象とする流域は，アジア高山域の水河を起源とす る 11 の大河川流域（インダス, ガンジス, ブラマプト ラ，長江，黄河，タリム，アムダリア，シルダリア， イラワジ，サルウィン，メコン）である（図-2). 水河 融解量の将来変化を明らかにするため, 水河モデル出 力值の水河融解量を利用して解析を行う。また, 各流 域の水資源への水河融解の影響を評価寸るため, 水河 モデル出力值の水河融解量と, GCM 出力值の河川流 出量を利用する. ここでは, 水河融解量と河川流出量 を足し合わせることにより, 流域内のすべての流出量 (総流出量) を表現することを行う。

なお本研究は，水河融解と水資源に関する研究の第一 段階であるため，水河内部における水河融解量の一時的 な貯留や，水河融解量と河川流出量の流域河口までの輸

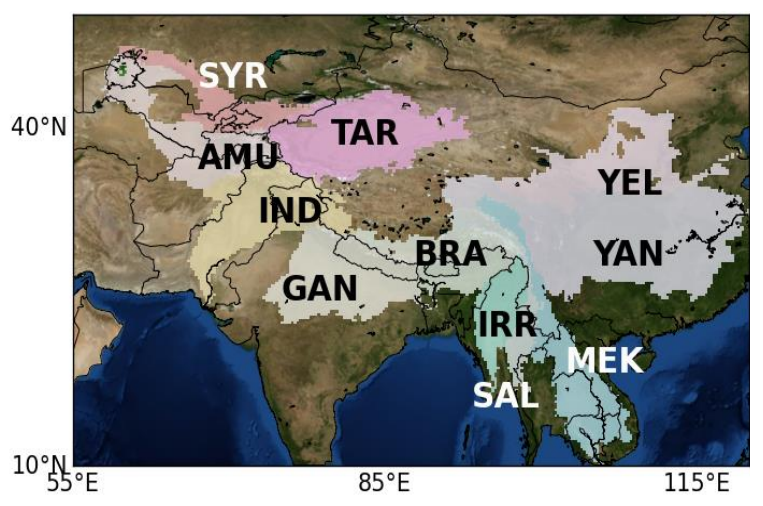

図-2 対象流域

TAR: タリム, SYR: シルダリア, AMU: アムダリア,

IND: インダス, GAN：ガンジス, BRA: ブラマプトラ,

IRR: イラワジ, SAL: サルウィン, MEK：メコン,

YAN：長江, YEL：黄河

送過程を計算していない. そのため，1年以上の期間であ れば，氷河内部の一時的な水河融解水の貯留が無視でき 9)，流域内の水収支は，ほぼ釣り合いがとれるという想定 に基づき, 水河融解量, 河川流出量, 総流出量のすべて について，年平均值を用いて，解析・議論を行う.

\section{（2）水河融解量（水河モデル）}

本研究で用いた水河モデル (HYOGA2) ${ }^{10}$ は，日気 温と日降水量を入力值として水河質量収支を計算する. 水河融解量は，積算気温法に基づいて計算される．積 算気温法に必要な水河上の積雪と水河の融解係数は, 観測值の長期平均に最も近づくようにキャリブレーシ ヨンされ，0.5グリッド毎に決定している．気温は， $0.0065^{\circ} \mathrm{C} / \mathrm{m}$ の一定の気温減率で標高帯毎に変化させた. また，降水は雪として降る場合のみ，質量収支に影響 すると想定している. 積雪は, 水河上に 1 年以上残留 した場合に涵養に使われる，氷河面積の計算は，面積一 体積の関係式を適用してもとめた.

ただし，過去期間は，観測を基にした降水と気温デ ータ（H08） 11)を与えたシミュレーションであり，将来 期間は，GCM の降水と気温とを H08 を用いてバイア ス補正を適用したもの ${ }^{12)}$ を水河モデルに与えたシミュ レーションである.

HYOGA2 の過去シミュレーションの結果は, 観測值 の質量収支を用いた検証により，その妥当性が示され ている ${ }^{10)}$. モデル出力值の質量収支と, 観測值の質量 収支との平均二乗誤差は，既存の全球水河モデルの誤 差推定值の範囲内となることが確認されている ${ }^{10)}$.

\section{（3）河川流出量 (GCM)}

河川流出量は, 各GCMが算定した流出量を, Global Soil Wetness Project 2 (GSWP2） ${ }^{13)}$ による複数陸面モデルの マルチモデル平均の月流出量解析の気候值に合うように 補正して利用した。河道モデル， the Catchment-based 


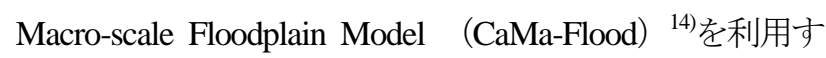
ることにより, 補正前, 補正後それぞれのGCM出力值の 流出量から, 河川流量をもとめ, Global Runoff Data Center

（GRDC）の67地点の観測值の河川流量と比較し，検証 を行った. 検証の結果，補正前後の相関係数は，0.89か ら0.95八向上し，その妥当性が確認された.

\section{（4）シミュレーション設定}

気候変化への顕著なシグナルを検出するため, 将来期 間（2006-2099年）では，RCP8.5の気候シナリオに基づい てシミュレーションを行う。用いるGCMは，CMIP5（第 5期結合モデル相互比較計画）に提出された，6つのGCM の出力值を利用する. GCMの選出は，（1）独立した研 究機関により開発されていることと，(2) 日流出量，水 河モデルの入力值となる日地表面気温と日降水量の出力 值の利用可能性の2点を条件とした。これにより, CCCma-CanESM2, CNRM-CM5, INM-CM4, MPI-ESM-LR, MRI-CGCM3，NCC-NorESM1-Mの6つが選出された. 利 用可能なGCMをすべて利用する理由は，GCM選定によ る不確実性の幅を示すためである.

\section{（5）各出力値の解析方法}

水河モデル出力值の水河融解量と GCM 出力值の河 川流出量の解析方法は以下のとおりである.

a）水河融解プロセス
将来期間（2006-2099年）において，水河の気候変動 の応答として, 水河融解量の将来変化の長期的な傾向を

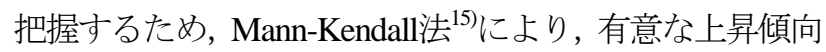
あるいは下降傾向の検定を行った．Mann-Kendall法は, データの大小関係や順序関係に基づいて傾向を推定する 手法である. 本研究では, 有意水準5\%を有意判定の基準 とした.

b）水河融解の水資源への影響

総流出量と, 総流出量に占める水河融解量の割合であ る水河寄与率の二つを, 流域毎に求める. ここで, 前述 したとおり, 水河融解量を求めるために利用した HYOGA2の質量収支と, 河川流出量を求めるために利用 したGCMの流出量は，それぞれ妥当性が検証されている。 したがって本研究では, HYOGA2とGCMの2種類の出力 值を足し合わせることにより, 総流出量を求める. なお, 水河を涵養する積雪以外の季節的な融雪と水河上の降雨 からの流出は, GCM出力值の河川流出量に含まれる.

\section{3. 結果}

水河面積は，ガンジス流域を除く 10 流域で，21世紀末 まで減少を続けた，水河融解量（流域内のすべての水河 から流出される水河融解量の流域平均值) の2006-2100年 の将来変化のトレンド解析結果から, ガンジスを除く 10

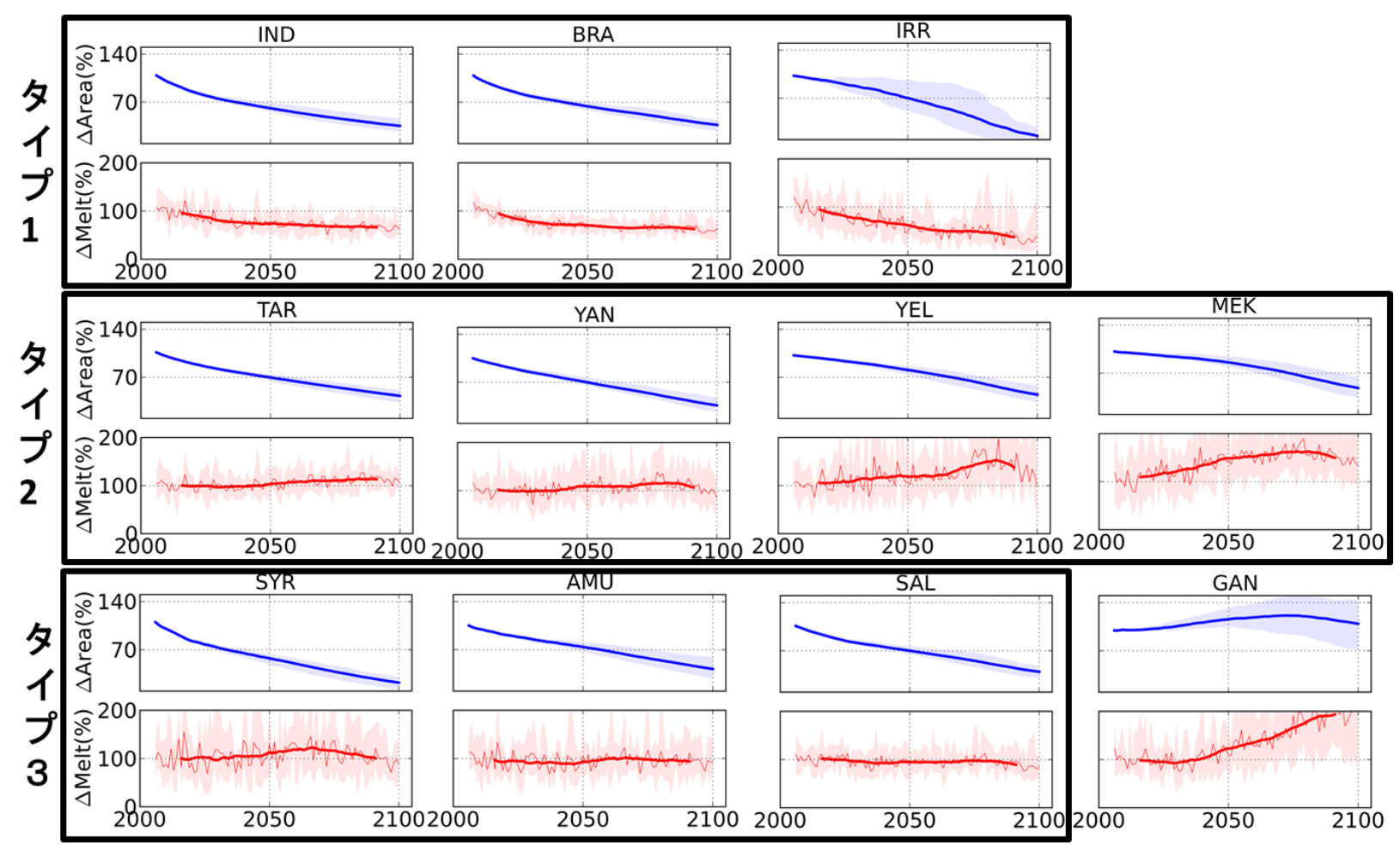

図-3 水河面積変化と氷河融解量変化

青線 : 水河面積変化率 (\%) は流域合計值を示す (2006-2015 年平均値比). 赤線 : 水河融解量変化率 (\%) は流域平均値 (2006-2015 年平均値比). すべて氷河モデル出力值. 各細線 : 6 つの GCM の年平均值, 陰影部 : GCM の幅, 各太線は 20 年の移動平均値. 

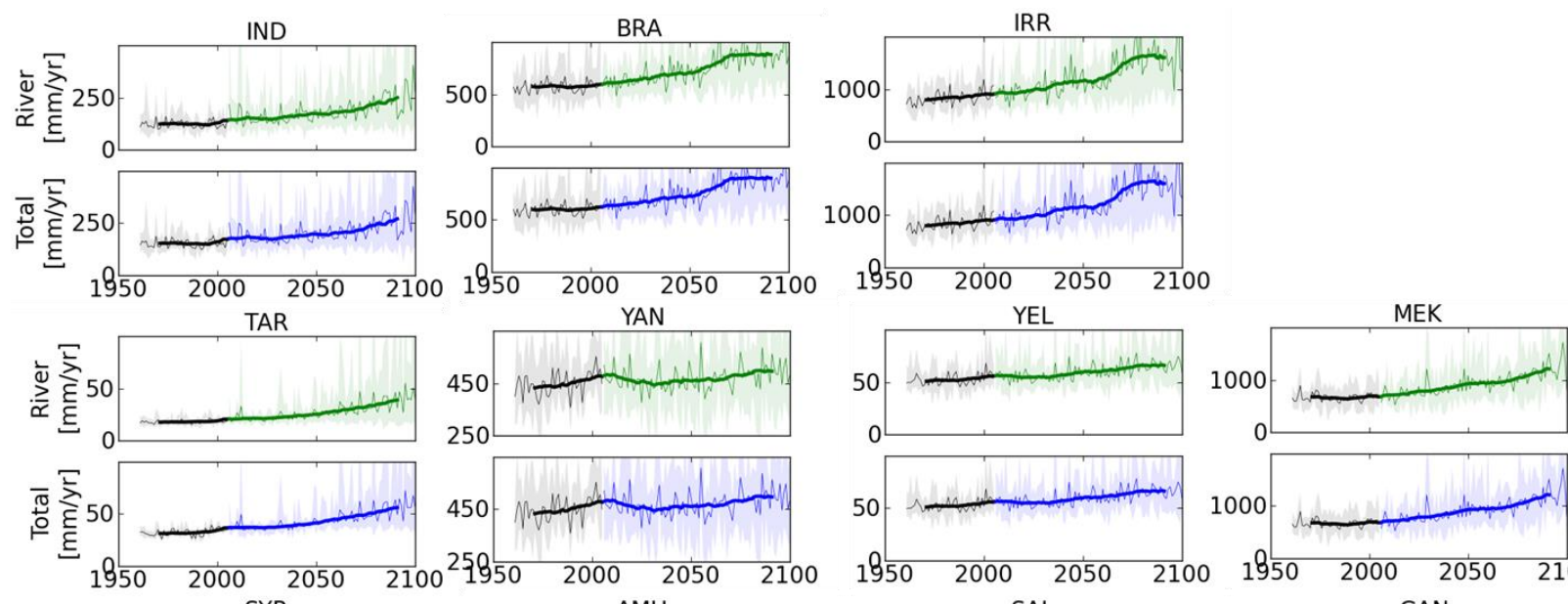

SYR
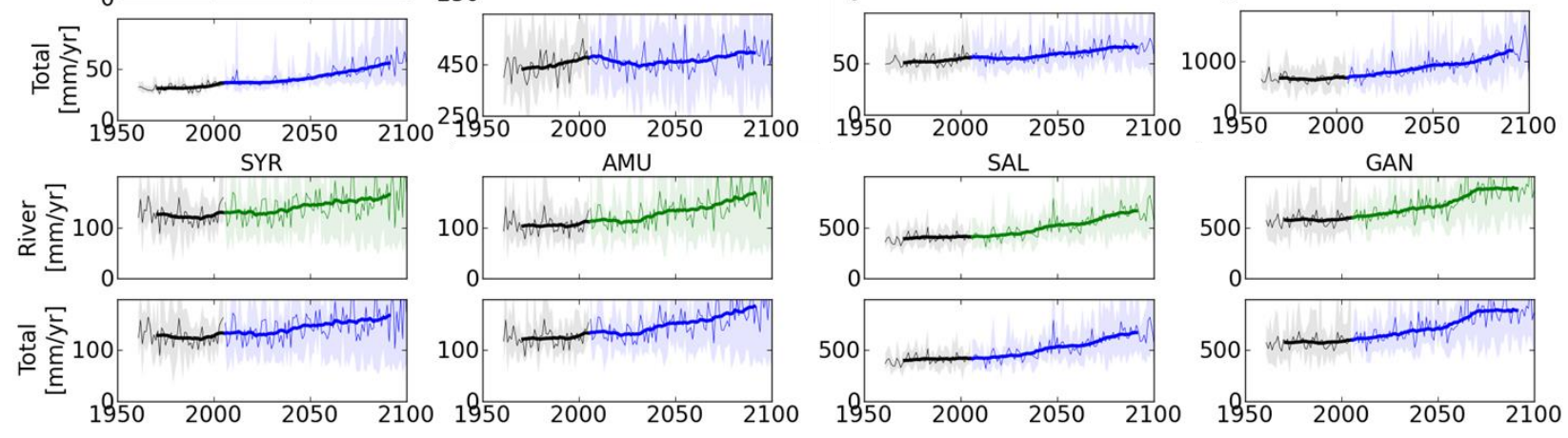

図-4 河川流出量 · 総流出量変化

各流域平均値示す. 緑線 : GCM から算定された河川流出量 $(\mathrm{mm} / \mathrm{yr})$; 青線 : 水河融解量と河川流出量を足し合わせた総流出量（mm /yr). 各細線 : 6 つの GCM の年平均値, 陰影部 : GCM の幅, 各太線は 20 年の移動平均値.

表-1 水河寄与率（\%）の変化（1961-1970 年平均値と 2091-2100 年平均値比較. 水河融解量（mm）の変化を括弧内に付記. ）

\begin{tabular}{|c|c|c|c|c|c|c|c|c|c|c|c|}
\hline & TAR & YAN & YEL & MEK & IND & BRA & IRR & SYR & AMU & SAL & GAN \\
\hline $\begin{array}{c}1961-1970 \\
\text { av. }\end{array}$ & $43(13)$ & $0.2(1)$ & $0.2(0)$ & $0.04(0)$ & $20(30)$ & $4(25)$ & $0.02(0)$ & $2(3)$ & $14(18)$ & $2(9)$ & $1(4)$ \\
\hline $\begin{array}{c}2091-2100 \\
\text { av. }\end{array}$ & $30(17)$ & $0.2(1)$ & $0.3(0)$ & $0.04(1)$ & $8(20)$ & $2(17)$ & $0.00(0)$ & $2(3)$ & $10(18)$ & $1(9)$ & $1(8)$ \\
\hline
\end{tabular}

流域を, 図-3のように3タイプに分けた. タイプ1のイン ダス, ブラマプトラ, イラワジの3流域は，下降傾向を示 した. タイプ2のタリム，長江，黄河，メコンの4流域は 上昇傾向を示した. タイプ3のシルダリア，アムダリア， サルウィンの3流域は有意な傾向が得られなかった.

河川流出量と, 水河融解量と河川流出量とを足し合わ せた総流出量は，いずれの流域においても，21世紀末ま で増加した（図-4)。総流出量は, 多くの流域で河川流出 量の増加に伴って増加した. 一方, 総流出量に占める水 河融解量の割合である水河寄与率は，いくつかの流域に おいて，21世紀末にかけて著しく減少することが予測さ れた（表-1）。タリム，インダス，ブラマプトラ，アムダ リア，サルウィン流域などで顕著な減少が予測された.

\section{4. 考察}

（1）水河融解プロセス

a）水河融解タイプの分類

タイプ 1 の水河融解量の 21 世紀における下降傾向
（図-3）は，氷河融解プロセス（図-1）の後半部分に 位置する減少時期に相当する可能性がある (図-5 (a)). つまり, タイプ 1 では氷河融解プロセスが比較的早く 進行するので, タイプ 1 を融解早型と分類する (図 -5 , 図-6)。融解早型では，シミュレーション期間である 21 世紀には, 寸でに氷河融解量の減少傾向を示寸ため, 水河融解量の増加から減少への転換点は, 21 世紀の初 期以前であると推測する. 一方，タイプ 2 の水河融解 量は，21 世紀には上昇傾向にある（図-3）。この上昇 傾向は, 氷河融解の前半部分に位置する増加時期に相 当する可能性がある（図-5 (b)). 寸なわち, タイプ2 では水河融解プロセスが比較的遅く進行するため, 夕 イプ 2 を融解遅型と分類する. タイプ 2 の水河融解量 は, シミュレーション期間中には, まだ増加傾向にあ るため, 一般的な水河融解プロセス (図-1） ${ }^{3)}$ を踏まえ ると, その転換点は, シミュレーション期間以降であ る 22 世紀もしくはそれ以降に訪れると推測する. タイ プ 3 の水河融解量は 21 世紀中, 顕著な傾向を検出する ことができなかった (図-3). 氷河融解プロセスのどの 時期に位置しているのか不明瞭であり, 変動型と分類 
(a)

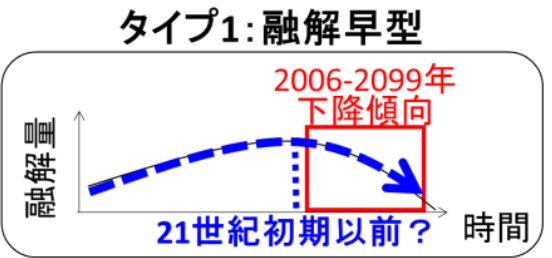

(b)

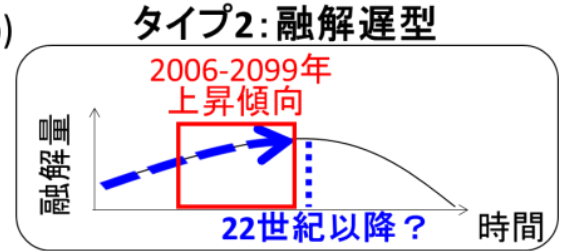

(c)

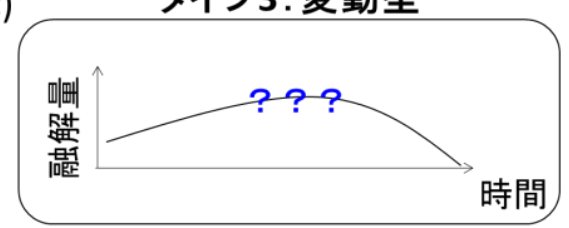

図-5 永河融解タイプ分類

タイプ1-3は，図-3のタイプ1-3に相当．黑実線は，図1に 示す長期的な融解量変化の概念図，青破線矢印は，本研究算 定結果である水河融解量変化 (2006 年-2099 年 (赤枠内)) と, 本研究の算定結果から推測する2006 年以前の融解量変化の概 念図を示す．（a），(b) の青文字でホした年代は，融解量のピ 一ク期.

した（図-5 (c)).

b）水河融解タイプの地理特性

融解早型に分類したインダス流域内の一部の支流域 では, 既存研究により, 水河融解の転換点は 2050 年前 後であることが予測されている ${ }^{5), 6 . ~ し か し な か ゙ ら ， イ ~}$ ンダス流域内の寸べての水河を対象とした本研究では, 融解ピークは 20 世紀以前であることが示唆された. 個 別の水河を対象とした場合と流域すべての氷河を対象 とした場合では水河の応答は異なることがわかった. さらに流域によっても氷河の応答は異なるため, 単一 の水河, 単一流域の水河は複数の流域における地域代 表性は示さないと考えられる.

3 タイプの水河融解プロセスの進行速度の違いは, 氷河が存在する領域の平均気温の違いによってもたら されるものと推測する. 図-7より, 融解早型では, 水 河の存在する領域の年平均気温が比較的高いのに対し, 融解遅型では, 水河の存在寸る領域の年平均気温が比 較的低いことがわかる. 本研究で利用した水河モデル を用いた温暖化実験では，水河の融解量は，積算気温 法により計算され，融水限界気温を超えた気温上昇量 に伴って増加寸るため, 融解早型と比較すると, 融解 遅型の水河の縮小は穏やかに進行したと考えられる. なお，氷河の存在する領域の年平均降雪量を解析した 結果，水河融解タイプを特徵づけるための顕著な傾向 を示さなかった（紙面の都合上，図には示さない)。ま た，本研究で用いた水河モデルでは，降水は雪として

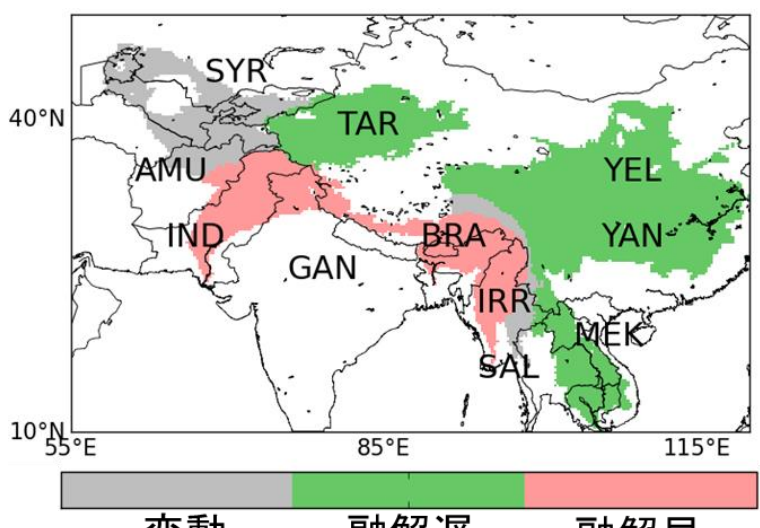

\section{変動 融解遅 融解早}

図-6＼cjkstart水河融解タイプ分布図

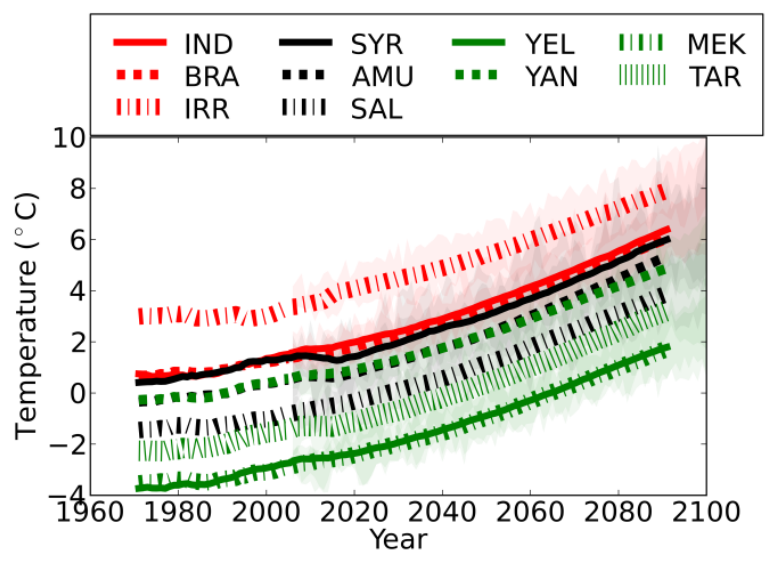

図-7 水河領域の年平均気温

各流域の水河の存在する領域の年平均気温 (20 年移動平均值). 赤, 黒, 緑各線: 6 つの GCM の平均值 ; 陰影部 : GCM の幅

降る場合のみ，質量収支に影響すると想定しているた め，降雨量は氷河融解量に影響を与えない．

\section{（2）水河融解の水資源への影響}

\section{a) 総流出量}

いずれの流域においても，降雨起源の流出が卓越す る河川流出量の増加が主な要因となって, 年総流出量 は増加することが予測された（図-4）。年平均流出量の 増加予測は, インダス, ガンジス, ブラマプトラ, サ ルウィン，メコンの上流からの流出量が，21 世紀の中 頃に増加するとする既存研究の予測結果 ${ }^{8}$ に一一致する. 水河融解量の将来変化が下降傾向を持つ融解早型の流 域においても，水河融解量の減少分を河川流出量の増 加分が相殺している. 年間降水量が少なく, 水河への 依存度が高いタリム，シルダリア，アムダリアなどに おいても, 水河融解水以外の要素が主な要因となって, 年平均総流出量は増加することが新たに分かった.

b）水河寄与率

いつくかの流域では過去から将来の顕著な水河寄与 率の減少が予測され (表-1), 氷河融解水の卓越寸る乾 季などの水供給への影響が深刻化することが示唆され 
た. インダス流域やブラマプトラ流域では, 水河融解 量の減少と河川流出量の増加により, 水河寄与率は 21 世紀末にかけて減少することが予測された。アムダリ ア流域，サルウィン流域では，水河融解量はほぼ変化 せず，河川流出量が増加したことにより，水河寄与度 は減少することが予測された．特筆すべきは，タリム 流域のケースで, 水河融解量は将来増加することが予 測されたにも関わらず，河川流出量の増加はさらにそ れを上回るため, 顕著な水河寄与率の減少が予測され た.

\section{5. 結論}

本研究では，水河融解量の将来変化を解析すること により，各流域の水河の気候変化への応答について議 論した. また, 水河融解量と, 河川流出量とを組み合 わせることで，流域全体における水河融解の水資源へ の影響を定量化した。

\section{（1）水河融解プロセス}

水河の気候变化への応答は，水河の存在する地理条 件 (水河の存在する領域の年平均気温) により異なる. 水河融解の進行度合いの違いから, ガンジスを除いた 10 流域を 3 タイプ (融解早型, 融解遅型, 変動型) に 分けた. また，各タイプの水河融解量の転換点は，融 解早型では 21 世紀の初期以前, 融解遅型では 22 世紀 以降であると推測する。

\section{（2）水河融解の水資源への影響}

年総流出量は, 主に水河融解水以外の要素の増加が 要因となって, 対象の全 11 流域で, 将来増加すること が予測された. 水河融解量の変化は, アジア高山域下 流の大河川の年総流出量の変化にはあまり寄与しない ことが明らかとなった. しかしながら, 水河融解量の 減少が要因となって氷河寄与率が将来著しく減少する ことが予測されたインダス，ブラマプトラでは，乾季 などの水供給に特に深刻な影響を及ぼす可能性がある。

\section{(3) 課題}

季節毎の流出量への水河融解の影響を定量化するこ とは, 本研究の次のステップとして残されている.ま た，対象期間の短さや，限られた水河モデルや気候シ ナリオを用いることは，結論へ不確実性をもたらす可 能性があるため, 22 世紀以降の継続的なシミュレーシ ヨンや，マルチモデル，マルチシナリオを用いること も今後考慮する必要がある.

謝辞：本研究は JSPS 科研費 25008718，24560617, 23226012, JSPS「アジア研究教育拠点事業」の助成を受
けた.

\section{参考文献}

1) IPCC 2014 Climate Change 2014: Impacts, Adaptation, and Vulnerability. Contribution of Working Group II to the Fifth Assessment Report of the Intergovernmental Panel on Climate Change (Cambridge: Cambridge University Press)

2) IPCC 2007 Climate Change 2007: .Impacts, Adaptation, and Vulnerability Contribution of Working Group II to the Fourth Assessment Report of the Intergovernmental Panel on Climate Change (Cambridge: Cambridge University Press)

3) Barnett, T. P., et al.,: Potential impacts of a warming climate on water availability in snow-dominated regions. Nature, 438, 303-309, 2005.

4) Jansson, P., et al., T.: The concept of glacier water storage - a review, J. Hydrol., Vol.282, pp.116-129, 2003.

5) Rees H. G. and Collins D. N.: Regional differences in response of flow in glacier-fed Himalayan rivers to climatic warming, Hydrol. Processes, 20, 2157, 2006.

6) Immerzeel WW, et al.,: Rising river flows throughout the twenty-first century in two Himalayan glacierized watersheds, 10.1038/NGEO1896, 2013.

7) Immerzeel WW, et al.,: Climate Change Will Affect the Asian Water Towers, Science, 328, 1382,, 2010.

8) Lutz A., F., et al.: Consistent increase in High Aisa's runoff due to increasing glacier melt and precipitation, Nat. Clim. Change, 2014.

9) Curry, K. M. and Paterson, W. S. B., The Physics of Glaicer Fourth Edition, Elsevier, 2010

10) Hirabayashi, Y. et al.,: Projection of mass changes of glaciers under a high-emission climate scenario by a global glacier model HYOGA2, Hydro. Res. Letter. 7(1) 6-11., 2013.

11) Hirabayashi Y, et al.,: A 59-year (1948-2006) global near-surface meteorological data set for land surface models. Part I: Development of daily forcing and assessment of precipitation intensity, Hydro. Res. Letter 2: 36-40, 2008.

12) Watanabe $S$, et al.,: Intercomparison of bias-correction methods for monthly temperature and precipitation simulated by multiple climate models, J. Geophys. Res. 117: D23114, 2012.

13) Dirmeyer, PA, et al., : Multimodel Analysis and Implications for Our Perception of the Land Surface, B. Am. Meteorol. Soc. 87 1391-1397, 2006.

14) Yamazaki, D, et al.,: A physically based description of floodplain inundation dynamics in a global river routing model, Water Resouces, 47, W04501, 10.1029/2010WR009726, 2011.

15) Gilbert,R.O.: 16.4 Mann-Kendall Test, Statistical methods for environmental pollution monitoring, ISBN 0-442-23050-8, 1987.

(2014. 9. 30 受付) 